\title{
Intimidation of Bacterial and Viral Infections in Humans
}

\author{
Prabhakar Reddy Veerareddy* \\ Palamuru University, India
}

*Corresponding author: Prabhakar Reddy Veerareddy, University College of

Pharmaceutical Sciences, Palamuru University, Mahabubnagar, Telangana State, India;

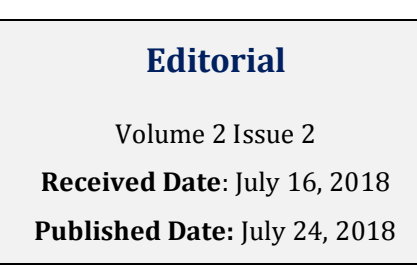

Email: vpreddyindia@gmail.com

\section{Editorial}

Viruses are very small microorganisms, size range from 15 to $400 \mathrm{~nm}$. Viruses cause a huge variety of diseases in animals, plants and humans. Viruses can be transmitted in diverse ways, when an infected person coughs by droplets, by contamination with stool samples, by sexual intercourse, by contact with blood, by contact with infected animals [1]. Bacterial and viral infections have a lot of things are in common. Both types of infections are caused by microbes (bacteria and viruses). Microbes cause coughing, sneezing, acute and chronic infections. Bacterial and viral infections also cause mild, moderate and severe diseases. Drews et. al, reviewed 1341 cases of respiratory viral infections detected with conventional techniques [2]. The mechanisms of bacteria and virus interactions were occurring either in the gastrointestinal tract or upper respiratory tract [3]. Bacterial and virus interactions are complex which results in enhanced pathogenesis and many papers have recognized the bacterial inhibition of viral infection [4]. Respiratory viruses follow recurring patterns of activity and cause pneumonia. Several viruses can be circulating at definite times of the year during the main epidemic peaks of one virus [5]. American Thoracic Society recommends that the diagnosis of pneumonia must be arranged on the basis of chest radiography [6]. Influenza vaccines used since 1940 and recognized as a role model in the obstacle of influenza A and B virus infections. Inactivated influenza vaccine is effective in young children (less than 3 years) [7]. Opportunities are very less in clinical observation for use of antiviral in the management of pneumonia [8]. Live-attenuated vaccines formed by reverse genetics are now in clinical studies [9]. World Health Organization (WHO) case definitions of surveillance of severe acute respiratory syndrome (SARS) were inevitable for surveillance [10]. The strategy for treatment in children with SARS was antibiotics and ribavirin with or without corticosteroids at different stages of the disease conditions [11]. Samples collected during an influenza type A epidemic in Britain (19891990) and cultured in MDCK cells, aspirates were cultured in LLC-MK2 cells. Nasal aspirates were cultivated in Ohio HeLa, clone 16 cells and HEp-2 cells [12]. The cytopathic effect of an isolate was established by acid stability testing, 5 immunofluorescence, electron microscopy or haemadsorption [13]. Earlier studies of upper respiratory infections has recommended that exposure with cell cultures missed many infections [14]. These were considered to be mostly rhinoviruses or undiscovered agents. Some Viral diseases are connected with defects in cellular immunity will reflect to reduce in the number of functional T cells [15]. Epidemic diarrhoea in infant mice (EDIM) is transmitted by airborne droplets [16] and rotavirus infection has related with respiratory symptoms in humans [17]. 2.5 Million People had hepatitis A virus (HAV) after consumption of contaminated clams in Shanghai, China [18]. Norovirus (NoV) is the frequent reason of gastroenteritis in all age group of people [19]. NoV infections can be diagnosed by image of virus particles by electron microscopy and RTPCR methods. Hepatitis E virus (HEV) variants were found in pigs and also found similar virus in some humans [20]. The prevention and detection of food borne viral infections should be evaluated vigilantly by WHO, NGOs and governments. Food service persons and catering Managers need to exclude food handlers with infectious symptoms to food borne diseases [21]. A small number of diarrheal diseases in the USA are recognized to bacterial pathogens [22].

Amebiasis caused by zoonotic protozoan parasite effect in no clinical symptoms from colitis, abscesses in the brain, liver and lungs. Humans and 240 species of 


\section{Open Access Journal of Pharmaceutical Research}

extant nonhuman primates are vulnerable to bacterial infections like salmonellosis, tuberculosis, campylobacter and shigellosis [23].

\section{References}

1. Koopmans M, Duizer E (2004) Food borne viruses: an emerging problem. Int J Food Microbiol 90(1): 23- 41.

2. Drews AL, Atmar RL, Glezen WP, Baxter BD, Piedra PA, et al. (1997) Dual respiratory virus infections. Clin Infect Dis 25(6): 1421-1429.

3. Murphy TF, Bakaletz LO, Smeesters PR (2009) Microbial Interactions in the Respiratory Tract. Pediatr Infect Dis J 28(10 suppl): S121-S126.

4. Abt MC, Osborne LC, Monticelli LA, Doering TA, Alenghat T, et al. (2012) Commensal Bacteria Calibrate the Activation Threshold of Innate Antiviral Immunity. Immunity 37(1): 158-170.

5. Makela MJ, Puhakka T, Ruuskanen O, Leinonen M, Saikku P, et al. (1998) Viruses and bacteria in the etiology of the common cold. J Clin Microbiol 36(2): 539-542.

6. Mandell LA, Wunderink RG, Anzueto A, Bartlett JG, Campbell GD, et al. (2007) Infectious Diseases Society of America/American Thoracic Society consensus guidelineson the management of communityacquired pneumonia in adults. Clin Infect Dis 44 (suppl 2): S27-72.

7. Heinonen S, Silvennoinen H, Lehtinen P, Vainionpaa R, Ziegler T, et al. (2010) Effectiveness of inactivated influenza vaccine in children aged 9 months to 3 years: an observational cohort study. Lancet Infect Dis 11(1): 23-29.

8. Wong SSY, Yuen KY (2008) Antiviral therapy for respiratory tract infections. Respirology 13(7): 950971.

9. Empey KM, Pebbles S, Koll JK (2010) Pharmacologic advances in the treatment and prevention of respiratory syncytial virus. Clin Infect Dis 50(9): 1258-1267.

10. (2003) World Health Organization. Case definitions for surveillance of sever acute respiratory syndrome (SARS).

11. Hon KLE, Leung CW, Cheng WTF, Chan PK, Chu WC, et al. (2003) Clinical presentations and outcome of severe acute respiratory syndrome in children. Lancet 361(9370): 1701-1703.
12. Philpotts RJ (1983) Clones of MRC-C cells may be superior to the parent line for the culture of 229E-like strains of human respiratory coronavirus. J Virol Methods 6(5): 267-269.

13. Schmidt NJ (1979) Cell culture techniques for diagnostic virology. In: Lennette EH, Schmidt NJ (Eds.), Diagnostic procedures for viral, rickettsial and chlamydial infections, Washington, DC American Public Health Association, Pp: 67-69.

14. Larson HE, Reed SE, Tyrrell DAJ (1980) Isolation of rhinoviruses and coronaviruses from 38 colds in adults. JMed Virol 5(3): 221-229.

15. Notkins AL, Mergenhagen SE, Howard RJ (1970) Effect of virus infections on the function of the immune system. Annu Rev Microbiol 24: 525-538.

16. Kraft LM (1957) Studies on the etiology and transmission of epidemic diarrhea of infant mice. J Exp Med 106(5): 743-755.

17. Carr ME, McKendrick GD, Spyridakis T (1976) The clinical features of infantile gastroenteritis due to rotavirus. Scand J Infect Dis 8(4): 241-243.

18. Halliday ML, Kang LY, Zhou TK, Hu MD, Pan QC, et al. (1991) An epidemic of hepatitis A attributable to the ingestion of raw clams in Shanghai, China. J Infect Dis 164(5): 852-859.

19. Wheeler JG, Sethi D, Cowden JM, Wall PG, Rodrigues LC, et al. (1999) Study of infectious intestinal disease in England: rates in the community, presenting to the general practitioner, and reported to national surveillance. The Infectious Intestinal Disease Study Executive. BMJ 318(7190): 1046-1050.

20. Meng XJ, Purcell RH, Halbur PG, Lehman JR, Webb DM, et al. (1997) A novel virus in swine is closely related to the human hepatitis E virus. Proc Natl Acad Sci USA 94(18): 9860-9865.

21. Cowden JM, Wall PG, Adak GK, Evans HS, Le Baigue S, et al. (1995) Outbreaks of foodborne infectious intestinal disease in England and Wales: 1992 and 1993. Commun Dis Rep CDR Rev 5(8): R109-R117.

22. Chin J (2000) Control of communicable diseases manual. 17th (Edn.), Washington American Public Health Association, Pp: 624.

23. Renquist DM, Whitney RA (1987) Zoonoses acquired from pet primates. Vet Clin North Am: Sm Anim Pract 17(1): 219-240. 